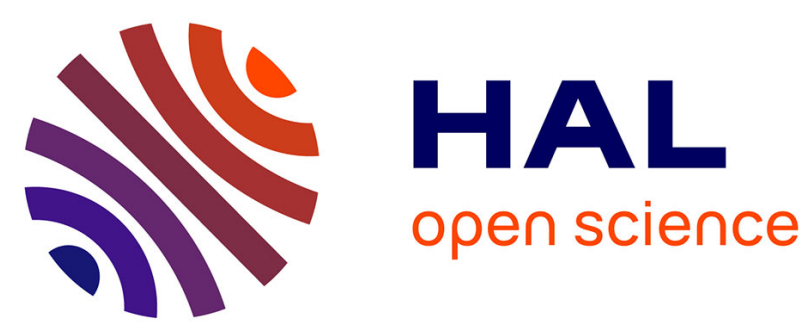

\title{
First Apatite (U-Th)/He and apatite fission-track thermochronology dataset from the Abancay Deflection (Eastern Cordillera, Southern Peru).
}

Benjamin Gérard, Xavier Robert, Laurence Audin, Cécile Gautheron, Matthias Bernet

\section{To cite this version:}

Benjamin Gérard, Xavier Robert, Laurence Audin, Cécile Gautheron, Matthias Bernet. First Apatite $(\mathrm{U}-\mathrm{Th}) / \mathrm{He}$ and apatite fission-track thermochronology dataset from the Abancay Deflection (Eastern Cordillera, Southern Peru).. Data in Brief, 2022, 40, pp.107748. 10.1016/j.dib.2021.107748 . hal03501753v1

\section{HAL Id: hal-03501753 \\ https://hal.science/hal-03501753v1}

Submitted on 23 Dec 2021 (v1), last revised 7 Jan 2022 (v2)

HAL is a multi-disciplinary open access archive for the deposit and dissemination of scientific research documents, whether they are published or not. The documents may come from teaching and research institutions in France or abroad, or from public or private research centers.
L'archive ouverte pluridisciplinaire HAL, est destinée au dépôt et à la diffusion de documents scientifiques de niveau recherche, publiés ou non, émanant des établissements d'enseignement et de recherche français ou étrangers, des laboratoires publics ou privés. 


\section{Journal Pre-proof}

First Apatite (U-Th)/He and apatite fission-track thermochronology dataset from the Abancay Deflection (Eastern Cordillera, Southern Peru).

Benjamin Gérard, Xavier Robert, Laurence Audin , Cécile Gautheron, Matthias Bernet

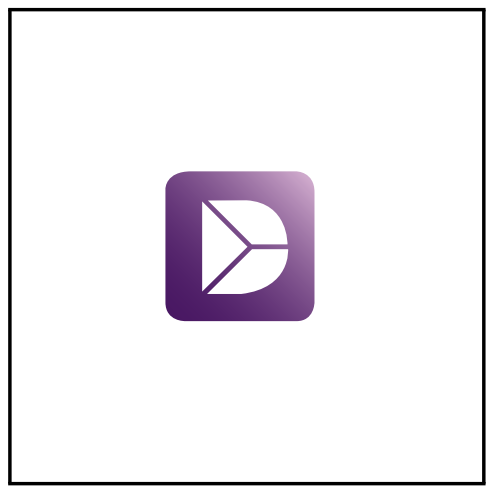

PII: S2352-3409(21)01023-4

DOI: https://doi.org/10.1016/j.dib.2021.107748

Reference: DIB 107748

To appear in:

Data in Brief

Received date:

29 September 2021

Revised date:

16 December 2021

Accepted date:

20 December 2021

Please cite this article as: Benjamin Gérard, Xavier Robert, Laurence Audin, Cécile Gautheron , Matthias Bernet, First Apatite (U-Th)/He and apatite fission-track thermochronology dataset from the Abancay Deflection (Eastern Cordillera, Southern Peru)., Data in Brief (2021), doi: https://doi.org/10.1016/j.dib.2021.107748

This is a PDF file of an article that has undergone enhancements after acceptance, such as the addition of a cover page and metadata, and formatting for readability, but it is not yet the definitive version of record. This version will undergo additional copyediting, typesetting and review before it is published in its final form, but we are providing this version to give early visibility of the article. Please note that, during the production process, errors may be discovered which could affect the content, and all legal disclaimers that apply to the journal pertain.

(C) 2021 Published by Elsevier Inc.

This is an open access article under the CC BY license (http://creativecommons.org/licenses/by/4.0/) 


\section{Article information}

\section{Article title}

First Apatite (U-Th)/He and apatite fission-track thermochronology dataset from the Abancay Deflection (Eastern Cordillera, Southern Peru).

\section{Authors}

Benjamin Gérard ${ }^{\star 1,2}$; Xavier Robert ${ }^{2}$; Laurence Audin $^{2}$; Cécile Gautheron ${ }^{3}$; Matthias Bernet ${ }^{2}$

\section{Affiliations}

${ }^{1}$ GET, Université de Toulouse, CNRS, IRD, UPS, Toulouse, France

${ }^{2}$ Université Grenoble Alpes, Université Savoie Mont Blanc, CNRS, IRD, IFSTTAR, ISTerre, Grenoble, France

Université Paris-Saclay, CNRS, GEOPS, Orsay, France

\section{Corresponding author's email address and Twitter handle}

benjamin.gerard@get.omp.eu

twitter: @GrardBenjamin2

\section{Keywords}

In-situ apatite; Abancay Deflection magmatic bodies; (U-Th)/He data; Fission-track data; Peru; Eastern Cordillera; Altiplano; Upper crust cooling dynamic.

\section{Abstract}

According to their respective temperature sensitivities, Apatite (U-Th)/He (AHe) and apatite fission-track (AFT) thermochronology records the thermal evolution of the upper crust $(<5 \mathrm{~km})$ and is a key for distinguishing between different exhumation mechanisms through timeevolving rock uplift, and landscape evolution. We applied these methods to extract the thermal evolution of the upper crust in the Abancay Deflection at the northern edge of the Altiplano (southern Peru). We present 120 single-crystal AHe ages (from 31 samples) and 27 AFT central ages obtained from magmatic bodies across the study area. AHe ages range from $0.6 \pm 0.1$ to $35.8 \pm 2.9$ Ma with a satisfactory reproducibility of single-crystal AHe ages with less than $10 \%$ averaged dispersion. AFT ages range from $2.6 \pm 1.9$ to $38.2 \pm 4.4 \mathrm{Ma}$ with $\mathrm{P}\left(\chi^{2}\right)$ values $>5 \%$. 
This dataset allows exploring the crust evolution from the late-Eocene to the Quaternary. Data processed and interpreted in the related article published in Tectonics (Gérard et al., 2021) are stored in PANGAEA repository (108 AHe single-grain ages and 27 AFT ages). We furthermore present in this article 12 extra single-grain AHe ages obtained after the related article publication. We also present the details of fission-track length measurements published in the related article. Thermochronological ages could be reused for testing He diffusion or fission track annealing processes or investigating the broader tectonic/geodynamic evolution of the Andes.

\section{Specifications table}

\begin{tabular}{|l|l|}
\hline Subject & Geology \\
\hline $\begin{array}{l}\text { Specific } \\
\text { subject area }\end{array}$ & Thermochronological dating methods aimed at determining cooling of rocks. \\
\hline Type of data & $\begin{array}{l}\text { 4 Tables - this article } \\
\text { 1 Figure - this article } \\
\text { 3 Tables (metadata, AHe data, AFT data - from the related research article) } \\
\text { stored in the PANGAEA repository [1] }\end{array}$ \\
\hline $\begin{array}{l}\text { How the data } \\
\text { were acquired }\end{array}$ & $\begin{array}{l}\text { Rock samples were collected during a field trip in the Abancay region (Peru) } \\
\text { in 2017. For each sample, 5- 10 kg of rocks were collected from magmatic } \\
\text { lithologies. Apatite (U-Th)/He ages were obtained via mass spectrometry } \\
{[2,3] . \text { Apatite fission-track ages were obtained using the external detection }} \\
\text { method (optical microscopy at 1250 x magnification) and calculated with the } \\
\text { BINOMFIT program [4]. }\end{array}$ \\
\hline Data format & $\begin{array}{l}\text { Raw } \\
\text { Analyzed } \\
\text { Filtered }\end{array}$ \\
\hline $\begin{array}{l}\text { Description of } \\
\text { data collection }\end{array}$ & $\begin{array}{l}\text { Apatites were concentrated according to standard crushing, sieving, electro- } \\
\text { magnetic and heavy liquid mineral separation techniques. AHe and AFT } \\
\text { dating protocols were performed under standard laboratory conditions. (U- } \\
\text { Th)/He ages were obtained after He, U, Th, Sm and Ca content } \\
\text { measurements for each single-crystal. 4He content was determined after }\end{array}$ \\
\hline
\end{tabular}




\begin{tabular}{|c|c|}
\hline & $\begin{array}{l}\text { single-crystal degassing under vacuum and analyzed by quadrupole mass } \\
\text { spectrometry using a calibrated }{ }^{3} \mathrm{He} \text { spike content. U, Th, Sm and Ca } \\
\text { contents were obtained after acid digestion and mass spectrometry analysis } \\
\text { with the use of spikes. }\end{array}$ \\
\hline $\begin{array}{l}\text { Data source / } \\
\text { location }\end{array}$ & $\begin{array}{l}\text { - Region: Apurimac and Cuzco } \\
\text { - Country: Peru } \\
\text { - Latitude and longitude for collected samples/data (coverage): South- } \\
\text { bound Latitude: }-13.686510^{\circ} \text {; West-bound Longitude: }-73.210850^{\circ} \text {; } \\
\text { North-bound Latitude: }-12.647520^{\circ} \text {; East-bound Longitude:- } \\
72.072520^{\circ}\end{array}$ \\
\hline $\begin{array}{l}\text { Data } \\
\text { accessibility }\end{array}$ & $\begin{array}{l}\text { With the article (Tables } 1,2,3 \& 4 \text { ) and online at PANGAEA [1] } \\
\text { Repository name: PANGAEA } \\
\text { Data identification number: PDI-26845 } \\
\text { Direct URL to data: } \text { https://doi.org/10.1594/PANGAEA.929199 - Metadata } \\
\text { https://doi.org/10.1594/PANGAEA.929196 - AHe data } \\
\text { https://doi.org/10.1594/PANGAEA.929194 - AFT data }\end{array}$ \\
\hline $\begin{array}{l}\text { Related } \\
\text { research } \\
\text { article }\end{array}$ & $\begin{array}{l}\text { B. Gérard, X. Robert, L. Audin, P.G. Valla, M. Bernet, C. Gautheron, } \\
\text { Differential exhumation of the Eastern Cordillera in the Central Andes: } \\
\text { Evidence for south-verging backthrusting (Abancay Deflection, Peru), } \\
\text { Tectonics. (2021). https://doi.org/10.1029/2020TC006314. }\end{array}$ \\
\hline
\end{tabular}

\section{Value of the data}

- The dataset fills a thermochronological data gap in this remote area of Peru.

- These AHe and AFT data allow to explore the tectonic and erosional dynamics of the Eastern Cordillera and northern Altiplano region (Abancay Deflection)[5][6]

- The data can be integrated at a larger scale and numerically processed for 3D geodynamic investigation (Thermo-kinematics PECUBE forward and inverse modelling [7][8]; Inverse Glide Model [9]).

- The dataset are valuable to unravel the regional thermal evolution and can be further processed by researchers with other geochronological data. 
- These thermochronological data allowed us to propose a new view/model of the Abancay Deflection tectonics as a proto-syntaxis rather than a simple fold-and-thrust system [5].

- AFT data can be used for testing or validation of fission-track annealing models [10]

\section{Data description}

The data files processed in the related research article are available at PANGAEA [1]. All data files can be downloaded in html or Excel format (tables). All variables displayed are clearly specified in the tables. The metadata file contains the sample name, the sampling date, the geological unit sampled, its precise location and elevation information: https://doi.org/10.1594/PANGAEA.929199. The AHe data (https://doi.org/10.1594/PANGAEA.929196) and AFT data (https://doi.org/10.1594/PANGAEA.929194) tables contain all necessary data and information for their respective analytical protocol.

We also present in this article 12 extra single-crystal AHe ages from 3 samples (AB-17-06, AB-17-15 and AB-17-24). Details regarding the sample locations and lithologies are presented in Table 1. AHe ages are presented in Table 2. Apatite fission-track measurements details (corresponding to the published fission-track ages published in [5]) are given in Table 3 . Finally, Table 4 presents the summary of mean fissiontrack length measurements and the associated errors computed using the HeFTy 1.9.1 program [11].

\section{Experimental design, materials and methods}

The Andes are the classical and systemic example of a Cordilleran-type active orogen, with mountain-building related to a subduction zone. Despite numerous studies of the exhumation setting, several phases of its long-term orogeny remain unsolved spatially or poorly documented. To address this, new thermochronological data are provided in this study. Apatite $(\mathrm{U}-\mathrm{Th}) / \mathrm{He}(\mathrm{AHe})$ and apatite fission-track (AFT) thermochronology are based on He and fission track production during alpha decay of ${ }^{238} \mathrm{U},{ }^{235} \mathrm{U}$, ${ }^{232} \mathrm{Th}$, and ${ }^{147} \mathrm{Sm}$ and fission decay of ${ }^{238} \mathrm{U}$, respectively. As a result, associated ${ }^{4} \mathrm{He}$ and fission tracks will accumulate within apatite crystals. Because of its temperature sensitivity, apatite low-temperature thermochronology records the thermal evolution of the upper crust $(<5 \mathrm{~km})$ and is a key for distinguishing between different exhumation mechanisms through time-evolving rock uplift, and landscape evolution. We applied these methods to extract the thermal evolution of the upper crust in the Abancay Deflection at the northern edge of the Altiplano (southern Peru). Thermochronological data presented in this study were derived from the analysis of magmatic apatites. We collected samples of igneous rocks (Granite, Monzonite, Diorite, Gabbro, Orthogneiss) across the Abancay Deflection in order to have optimal thermochronological data coverage with the aim of carrying out thermokinematic numerical modelling of the upper crust in this uninvestigated remote part of the Peruvian Andes. The Abancay Deflection is located at the northern edge of the Peruvian Altiplano. Its hinge-like morphology is emphasized by the deflection of its fault patterns, its internal cordilleras and its captured hydrographic networks from the overall elongation axis of the Andes (deflection $>45^{\circ}$ ). The study area encompasses two distinct morphotectonic regions; the Altiplano southward, characterized by Eocene plutons emplaced into Meso-Cenozoic sediments, and the Eastern Cordillera northward, characterized by Permo-Triassic plutons emplaced into Paleozoic metasediments [5]. These plutons were preferentially targeted for sampling during the fieldwork. 
The experimental design, materials and methods description hereafter is based on the method section published in [5]. Parts of the text may be similar. The paragraphs presented hereafter are, however, more detailed and information about the analytical protocol and procedure have been added.

As far as possible, we sampled in-situ outcropping bedrock in the field (5-10 kg per sample). Apatites were concentrated according to standard crushing, sieving, electro-magnetic and heavy liquid mineral separation techniques. Magmatic rock samples were crushed cold and sieved at the Géode Laboratory (Lyon, France) to extract the 100-160- $\mu \mathrm{m}$ grain size fractions. The mineral separation techniques were performed at the GeoThermoChronology (GTC) platform within the ISTerre Laboratory (Université Grenoble Alpes, France).

In the context of AHe dating, apatite crystals were carefully selected a under binocular microscope to manually select minerals without fractures and/or inclusions. This strict selection was performed in order to prevent biases in the computation of AHe ages. We removed minerals that included these defects from the analytical procedure to avoid any potential additional source of ${ }^{4} \mathrm{He}$, or $\mathrm{He}$ diffusion artifacts [12] (Figure 1a). Selected minerals were then measured in three dimensions (length, width and thickness) with a digital ruler. We determined the individual grain geometry (to compute the sphere equivalent radius of hexagonal crystal $\left(\mathrm{R}_{\mathrm{s}}\right)$ ) and calculated the $\alpha$-ejection correction factor using the Qt_FT program [13][14][15] (based on Monte Carlo simulation). The $\alpha$-ejection correction factor was computed from the crystal dimensions. This takes into account the loss of $\mathrm{He}$ atoms located beneath the grain boundaries. Small crystals would consequently lose a larger proportion of He during ejection than large grains. We selected five replicates per sample for analysis. Some samples present less than five aliquots analysed because the number of suitable apatites for AHe dating was too low or because He content extracted from the mineral after analysis was too close from the blank to be reliable. After this first phase of identification, we encapsulated individual apatites in platinum tubes (Figure 1b). Each platinum tube and the apatite it contains were heated under high vacuum conditions at high temperature $\left(1,050 \pm 50^{\circ} \mathrm{C}\right)$ twice for $5 \mathrm{~min}$ at GEOPS Laboratory (Université Paris-Saclay, France). The released ${ }^{4} \mathrm{He}$ gas was mixed with a known amount of ${ }^{3} \mathrm{He}$, purified, and the gas was analysed using a Prisma Quadrupole. The ${ }^{4} \mathrm{He}$ content was determined by isotope dilution method. Subsequently, apatite crystals were dissolved in $50 \mu \mathrm{L}$ of $\mathrm{HNO}_{3} 5 \mathrm{~N}$ solution containing known amount of ${ }^{235} \mathrm{U},{ }^{230} \mathrm{Th},{ }^{149} \mathrm{Sm}$, and ${ }^{42} \mathrm{Ca}$. The solution was heated at $70^{\circ} \mathrm{C}$ for $3 \mathrm{~h}$ and $900 \mu \mathrm{L}$ of distilled water was added. The final solution was analyzed using an ELEMENT XR ICP-MS (CCT-QMS series II at the LSCE laboratory at Gif sur Yvette, France) and the ${ }^{238} \mathrm{U},{ }^{230} \mathrm{Th}$, and ${ }^{147} \mathrm{Sm}$ concentrations and apatite weights (using the Ca content [16]) were obtained. Finally, AHe ages were computed following the methodology detailed in [3]. Durango apatite crystals were also analyzed over the same period to ensure the data quality. The $1 \sigma$ error on each AHe age amounts to $8 \%$, reflecting the analytical error and the uncertainty on the ejection factor correction [3].

Regarding the AFT dating, initial mounting and fission tracks revealing procedures were done at the GTC Laboratory (ISTerre, Grenoble France). Almost 3200 apatites were mounted in epoxy resin in Teflon molds (Figure 1c), polished, and etched for $20 \mathrm{~s}$ at $21^{\circ} \mathrm{C}$ using a $5.5 \mathrm{M}$ $\mathrm{HNO}_{3}$ solution to reveal spontaneous fission tracks. Using the external detector method [17-19], all samples were irradiated together with Durango and Fish Canyon Tuff age standards and IRMM540R dosimeter glasses at the FRM II reactor (Munich, Germany). Tracks were counted and horizontally confined track lengths were measured dry at 1,250X magnification under an Olympus BX51 optical microscope, using the FTStage 4.04 program at ISTerre. Only TinT (Track in Track) were measured following recommendations from [20]. We performed AFT 
central ages computation using the BINOMFIT program [4] according to the $\zeta$-calibration technique [17,19]. Measurement of five Durango and five Fish Canyon Tuff age standards allowed establishing a $\zeta$-value of $275 \pm 12$ to be constrained for the operator $B$. Gérard.

These thermochronological data were subsequently processed in thermo-kinematics model (PECUBE; [8]) after consideration regarding the geothermal gradient in order to test the upper crust evolution of the Abancay Deflection area. Indeed, PECUBE modelling allows quantification of thermal histories for rock particles at depth in exhumation or burial contexts. Details regarding thermal assumptions and cooling/exhumation histories for the crust are detailed and discussed in [5].

\section{Ethics statements}

Nothing to declare.

\section{CRediT author statement}

Benjamin Gérard: Conceptualization, Sampling, Investigation, Data Curation, Writing - Original Draft, Visualization. Xavier Robert: Conceptualization, Sampling, Investigation, Writing - Review \& Editing, Supervision, Funding acquisition. Laurence Audin: Conceptualization, Sampling, Investigation, Writing - Review \& Editing, Supervision, Funding acquisition. Cécile Gautheron: Methodology, Validation, Resources, Data Curation, Writing - Review \& Editing, Funding acquisition. Miatthias Bernet: Methodology, Validation, Resources, Data Curation, Writing Review \& Editing.

\section{Acknowledgments}

This work was supported by the IRD (Institut de Recherche pour le Développement), ISTerre, the INSU (Institut National des Sciences de I'Univers), and the ANR-12-NS06-0005-01 project for the AHe analysis. We are grateful to the SERNANP, the INGEMMET (Cusco-PATA convenio 006-2016-Fondecyt), and the National Archaeological Park of Machu Picchu, for the provided facilities. We thank P. H. Leloup and G. Mahéo (Géode laboratory, Lyon) and the GTC platform (F. Coeur and F. Sénebier, ISTerre, Grenoble) for sample processing, as well as M. Balvay, R. Pinna-Jamme, and F. Haurine for assistance during AFT and AHe dating. We thank the two anonymous reviewers for instructive feedback on this manuscript.

\section{Declaration of interests}

$\otimes$ The authors declare that they have no known competing financial interests or personal relationships that could have appeared to influence the work reported in this paper. 


\section{References}

[1] B. Gérard, X. Robert, L. Audin, P. Valla, M. Bernet, C. Gautheron, Low-Temperature thermochronological data (AHe/AFT) for cooling dynamic investigation of the Abancay Deflection region (Southern Peru), 2017-2019, PANGAEA. (2021). https://doi.org/https://doi.org/10.1594/PANGAEA.929199.

[2] A. Recanati, C. Gautheron, J. Barbarand, Y. Missenard, R. Pinna-Jamme, L. Tassan-Got, A. Carter, E. Douville, L. Bordier, M. Pagel, K. Gallagher, Helium trapping in apatite damage: Insights from (U-Th-Sm)/He dating of different granitoid lithologies, Chem. Geol. 470 (2017) 116-131. https://doi.org/10.1016/j.chemgeo.2017.09.002.

[3] C. Gautheron, R. Pinna-Jamme, A. Derycke, F. Ahadi, C. Sanchez, F. Haurine, G. Monvoisin, D. Barbosa, G. Delpech, J. Maltese, P. Sarda, L. Tassan-Got, Technical note: Analytical protocols and performance for apatite and zircon (U-Th)/He analysis on quadrupole and magnetic sector mass spectrometer systems between 2007 and 2020, Geochronology. 3 (2021) 351-370. https://doi.org/https://doi.org/10.5194/gchron-3-351-2021.

[4] T.A. Ehlers, T. Chaudhri, S. Kumar, C.W. Fuller, S.D. Willett, R.A. Ketcham, M.T. Brandon, Computational Tools for Low-Temperature Thermochronometer Interpretation, Rev. Mineral. Geochemistry. 58 (2005) 589-622. https://doi.org/10.2138/rmg.2005.58.22.

[5] B. Gérard, X. Robert, L. Audin, P.G. Valla, M. Bernet, C. Gautheron, Differential exhumation of the Eastern Cordillera in the Central Andes: Evidence for south- verging backthrusting (Abancay Deflection, Peru), Tectonics. (2021). https://doi.org/10.1029/2020TC006314.

[6] B. Gérard, L. Audin, X. Robert, C. Gautheron, P. van der Beek, M. Bernet, C. Benavente, F. Delgado, Pliocene river capture and incision of the northern Altiplano: Machu Picchu, Peru, J. Geol. Soc. London. 178 (2021). https://doi.org/https://doi.org/10.1144/jgs2020-100.

[7] J. Braun, Pecube: A new finite-element code to solve the 3D heat transport equation including the effects of a time-varying, finite amplitude surface topography, Comput. Geosci. 29 (2003) 787-794. https://doi.org/10.1016/S0098-3004(03)00052-9.

[8] J. Braun, P. van der Beek, P. Valla, X. Robert, F. Herman, C. Glotzbach, V. Pedersen, C. Perry, T. Simon-Labric, C. Prigent, Quantifying rates of landscape evolution and tectonic processes by thermochronology and numerical modeling of crustal heat transport using PECUBE, Tectonophysics. 524-525 (2012) 1-28. https://doi.org/10.1016/j.tecto.2011.12.035.

[9] M. Fox, F. Herman, S.D. Willett, D.A. May, A linear inversion method to infer exhumation rates in space and time from thermochronometric data, Earth Surf. Dyn. 2 (2014) 47-65. https://doi.org/10.5194/esurf-2-47-2014.

[10] M.A. Rana, A.L. Lixandrao Filho, S. Guedes, A new phenomenological model for annealing of fission tracks in apatite: laboratory data fitting and geological benchmarking. Phys Chem Miner. 48 (2021). https://doi.org/https://doi.org/10.1007/s00269-021-01143-9.

[11] R.A. Ketcham, Forward and inverse modeling of low-temperature thermochronometry data, Rev. Mineral. Geochemistry. 58 (2005) 275314. https://doi.org/10.2138/rma.2005.58.11.

[12] K.A. Farley, (U-Th)/He Dating: Techniques, Calibrations, and Applications, Rev. Mineral. Geochemistry. 47 (2002) 819-844. https://doi.org/10.2138/rmg.2002.47.18.

[13] C. Gautheron, L. Tassan-Got, A Monte Carlo approach to diffusion applied to noble gas/helium thermochronology, Chem. Geol. 273 (2010) 212-224. https://doi.org/10.1016/j.chemgeo.2010.02.023. 
[14] R.A. Ketcham, C. Gautheron, L. Tassan-Got, Accounting for long alpha-particle stopping distances in (U-Th-Sm)/He geochronology: Refinement of the baseline case, Geochim. Cosmochim. Acta. 75 (2011) 7779-7791. https://doi.org/10.1016/j.gca.2011.10.011.

[15] C. Gautheron, L. Tassan-Got, R.A. Ketcham, K.J. Dobson, Accounting for long alpha-particle stopping distances in (U-Th-Sm)/He geochronology: 3D modeling of diffusion, zoning, implantation, and abrasion, Geochim. Cosmochim. Acta. 96 (2012) 44-56. https://doi.org/10.1016/j.gca.2012.08.016.

[16] W.R. Guenthner, P.W. Reiners, U. Chowdhury, Isotope dilution analysis of Ca and Zr in apatite and zircon (U-Th)/He chronometry, Geochemistry, Geophys. Geosystems. 17 (2016) 1623-1640. https://doi.org/10.1002/2016GC006311.

[17] A.J. Hurford, Standardization of fission track dating calibration: Recommendation by the Fission Track Working Group of the I.U.G.S. Subcommission on Geochronology, Chem. Geol. Isot. Geosci. Sect. 80 (1990) 171-178. https://doi.org/10.1016/0168-9622(90)90025-8.

[18] A.J. Hurford, P.F. Green, A users' guide to fission track dating calibration, Earth Planet. Sci. Lett. 59 (1982) 343-354. https://doi.org/10.1016/0012-821X(82)90136-4.

[19] A.J. Hurford, P.F. Green, The zeta age calibration of fission-track dating, Isot. Geosci. 1 (1983) 285-317. https://doi.org/10.1016/S00092541(83)80026-6.

[20] J. Barbarand, T. Hurford, A. Carter, Variation in apatite fission-track length measurement: Implications for thermal history modelling, 2003. https://doi.org/10.1016/S0009-2541(02)00423-0. 
Table 1. Sample locations and bedrock lithologies

\begin{tabular}{lccccc}
\hline Sample number & $\begin{array}{c}\text { Latitude } \\
\left({ }^{\circ} \mathrm{S}\right)\end{array}$ & $\begin{array}{c}\text { Longitude } \\
\left({ }^{\circ} \mathrm{W}\right)\end{array}$ & $\begin{array}{c}\text { Elevation } \\
(\mathrm{m})\end{array}$ & Lithology & Geologic unit \\
\hline $\mathrm{AB}-17-06$ & 13.07867 & 72.27952 & 3696 & Granite & Mesapelada pluton \\
AB-17-15 & 12.9652 & 72.07252 & 2475 & Granite & Colca pluton \\
AB-17-24 & 13.01515 & 72.96502 & 3839 & Granite & Kiteni pluton \\
\hline
\end{tabular}

Note: This table is a direct extension of the Table 1 in the related research article [5].

Table 2. Apatite (U-Th-Sm)/He data

\begin{tabular}{|c|c|c|c|c|c|c|c|c|c|c|c|c|c|c|c|c|}
\hline $\begin{array}{l}\text { Sample } \\
\text { number }\end{array}$ & Morphology & $\begin{array}{l}\text { Length } \\
( \pm 5 \mu \mathrm{m})\end{array}$ & $\begin{array}{c}\text { Width } \\
( \pm 5 \mu \mathrm{m})\end{array}$ & $\begin{array}{l}\text { Thickness } \\
( \pm 5 \mu \mathrm{m})\end{array}$ & $\begin{array}{c}\mathrm{R}_{\mathrm{s}} \\
(\mu \mathrm{m})\end{array}$ & $\begin{array}{c}\text { Weight } \\
(\mu \mathrm{g})\end{array}$ & $\mathrm{F}_{\mathrm{T}}$ & $\begin{array}{c}{ }^{4} \mathrm{He} \\
\text { (nccSTP/g) }\end{array}$ & $\begin{array}{l}{ }^{238} \mathrm{U} \\
(\mathrm{ppm})\end{array}$ & $\begin{array}{l}{ }^{232} \mathrm{Th} \\
(\mathrm{ppm})\end{array}$ & $\begin{array}{l}{ }^{147} \mathrm{Sm} \\
(\mathrm{ppm})\end{array}$ & $\mathrm{Th} / \mathrm{U}$ & $\begin{array}{c}\mathrm{eU} \\
(\mathrm{ppm})\end{array}$ & $\begin{array}{l}\text { Age } \\
\text { (Ma) }\end{array}$ & $\begin{array}{c}\text { Corrected Age } \\
\text { (Ma) }\end{array}$ & $\pm 1 \sigma$ \\
\hline$\overline{\mathrm{AB}-17-06 \mathrm{~A}}$ & $1 b+1 p y$ & 125 & 126 & 125 & 76 & 6.2 & 0.81 & 5126 & 47.9 & 157.5 & 90.5 & 3.3 & 86 & 0.5 & 0.6 & 0.1 \\
\hline $\mathrm{AB}-17-06 \mathrm{~B}$ & $2 b$ & 120 & 130 & 120 & 82 & 5.5 & 0.83 & 4716 & 50.1 & 81.3 & 44.4 & 1.6 & 70 & 0.6 & 0.7 & 0.1 \\
\hline AB-17-06C & $2 b$ & 124 & 143 & 124 & 86 & 5.7 & 0.83 & 17483 & 29.4 & 25.1 & 90.7 & 0.9 & 36 & 4.1 & 4.9 & 0.4 \\
\hline AB-17-06D & $2 b$ & 103 & 105 & 103 & 70 & 3.2 & 0.80 & 23045 & 35.2 & 27.2 & 95.4 & 0.8 & 42 & 4.6 & 5.7 & 0.5 \\
\hline AB-17-06E & $1 b+1 p y$ & 104 & 108 & 104 & 60 & 2.5 & 0.77 & 20264 & 40.8 & 20.8 & 100.8 & 0.5 & 46 & 3.7 & 4.8 & 0.4 \\
\hline$\overline{A B}-17-15 A$ & $2 b$ & 99 & 106 & 139 & 68 & 3.2 & 0.79 & 10337 & 4.9 & 13.4 & 21.2 & 2.8 & 8 & 10.6 & 13.4 & 1.1 \\
\hline AB-17-15E & $1 b+1$ py & 69 & 97 & 134 & 43 & 1.4 & 0.68 & 12410 & 7.2 & 15.1 & 7.5 & 2.1 & 11 & 9.6 & 14.1 & 1.1 \\
\hline AB-17-24A & $2 b$ & 98 & 99 & 198 & 67 & 4.4 & 0.79 & 26281 & 62.5 & 91.7 & 64.7 & 1.5 & 85 & 2.6 & 3.3 & 0.3 \\
\hline AB-17-24B & $2 b$ & 89 & 102 & 120 & 61 & 2.3 & 0.77 & 74866 & 187.7 & 101.7 & 54.7 & 0.5 & 212 & 2.9 & 3.8 & 0.3 \\
\hline AB-17-24C & $2 b$ & 120 & 133 & 142 & 83 & 4.9 & 0.83 & 119789 & 119.4 & 20.5 & 21.7 & 0.2 & 124 & 8.0 & 9.6 & 0.8 \\
\hline AB-17-24D & $1 b+1 p y$ & 91 & 112 & 169 & 57 & 2.9 & 0.75 & 60087 & 63.3 & 37.0 & 17.5 & 0.6 & 72 & 6.9 & 9.2 & 0.7 \\
\hline $\mathrm{AB}-17-24 \mathrm{E}$ & $1 b+1$ py & 111 & 136 & 145 & 66 & 3.4 & 0.78 & 62631 & 59.4 & 79.0 & 32.3 & 1.3 & 79 & 6.6 & 8.5 & 0.7 \\
\hline
\end{tabular}

Note: Morphology refers to the apatite geometry. 2py: 2 hexagonal pyramids; $2 b: 2$ broken faces; $1 b+1$ py: 1 broken face \& 1 hexagonal pyramid. $F_{T}$ is the alpha ejection correction factor and $R s$ is the sphere equivalent radius of hexagonal crystal. This table is a direct extension of the Table 2 in the related research article [5]. 


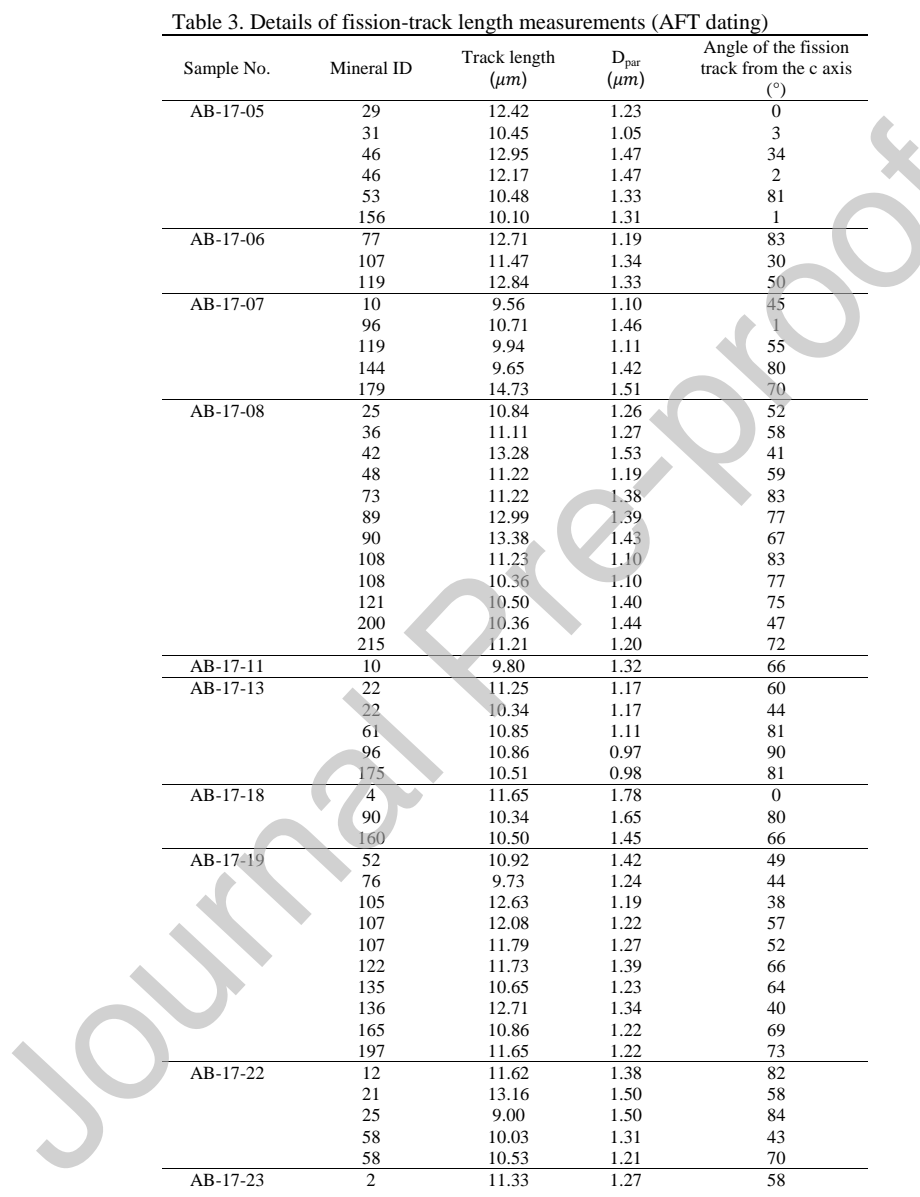

10 


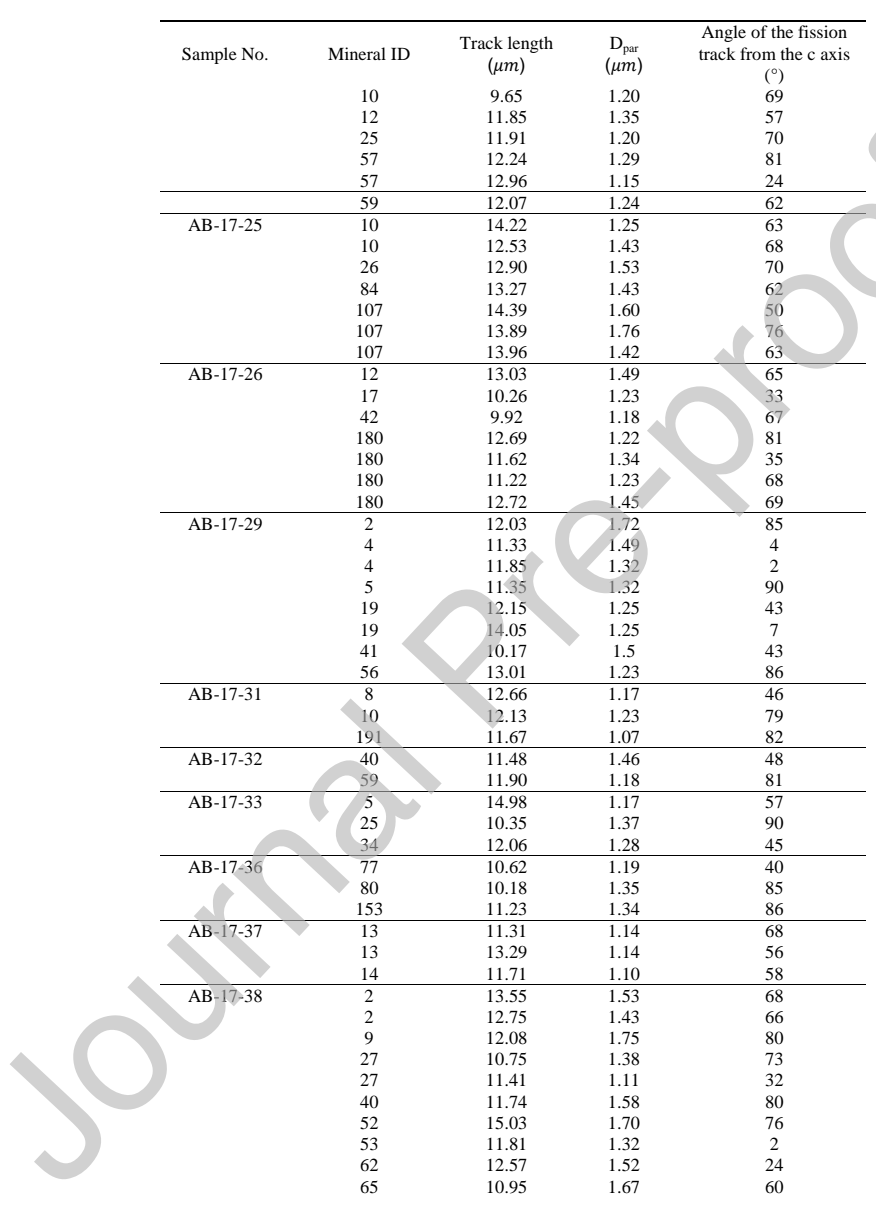

11 


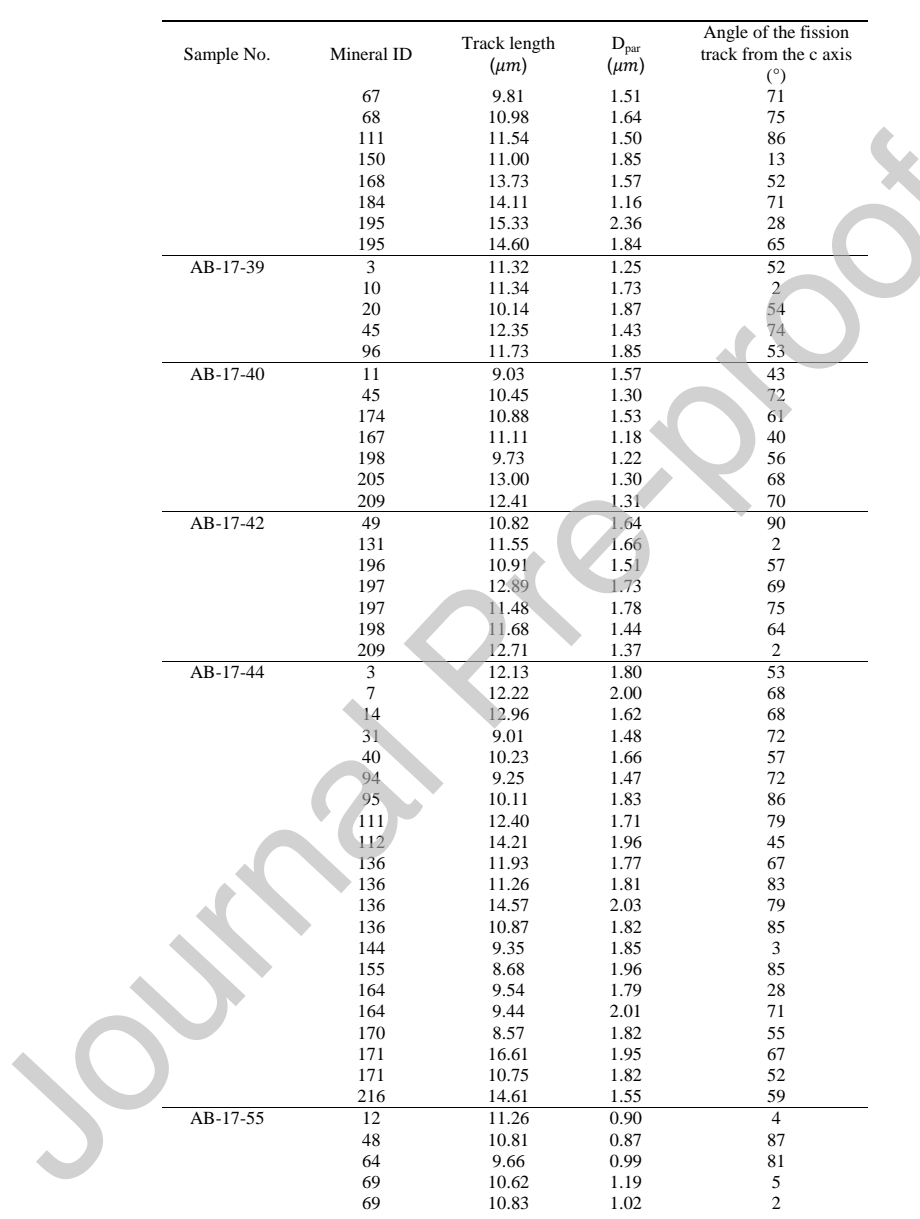

12 


\begin{tabular}{ccccc}
\hline Sample No. & Mineral ID & $\begin{array}{c}\text { Track length } \\
(\mu \mathrm{m})\end{array}$ & $\begin{array}{c}\mathrm{D}_{\text {par }} \\
(\mu \mathrm{m})\end{array}$ & $\begin{array}{c}\text { Angle of the fission } \\
\text { track from the c axis } \\
\left({ }^{\circ}\right)\end{array}$ \\
\hline & 100 & 11.08 & 0.84 & 53 \\
\hline
\end{tabular}

Notes: Horizontal track lengths were measured dry at 1,250X magnification under an Olympus BX51 optical microscope, using the FTStage 4.04. D par: fission -track etch figure diameter. $c$ axis: elongation axis of the apatite. Error of individual track lengths measurements is on the order of $8 \%$.

Table 4. Summary of mean fission-track length measurements (AFT dating)

\begin{tabular}{|c|c|c|c|c|c|}
\hline Sample No. & $\mathrm{n}$ & $\begin{array}{c}\text { Mean track length } \\
(\mu \mathrm{m})\end{array}$ & +/- 1 sigma error & $\begin{array}{l}\text { c-axis projected } \\
\text { mean track lengths } \\
(\mu \mathrm{m})\end{array}$ & $+/-1$ sigma error \\
\hline AB-17-05 & 6 & 11.43 & 1.22 & 12.00 & 1.44 \\
\hline AB-17-06 & 3 & 12.34 & 0.76 & 13.67 & 1.05 \\
\hline AB-17-07 & 5 & 10.92 & 2.18 & 12.61 & 1.84 \\
\hline AB-17-08 & 12 & 11.47 & 1.10 & 13.45 & 0.72 \\
\hline AB-17-11 & 1 & 9.80 & 0.00 & 12.46 & 0.00 \\
\hline AB-17-13 & 5 & 10,76 & 0.35 & 13.03 & 0.47 \\
\hline AB-17-18 & 3 & 10.83 & 0.71 & 12.50 & 0.74 \\
\hline AB-17-19 & 10 & 11.47 & 0.93 & 13.26 & 0.62 \\
\hline AB-17-22 & 5 & 10.87 & 1.59 & 13.15 & 0.98 \\
\hline AB-17-23 & 7 & 11.72 & 1.03 & 13.51 & 0.55 \\
\hline AB-17-25 & 7 & 13.59 & 0.70 & 14.84 & 0.41 \\
\hline AB-17-26 & 7 & 11.64 & 1.24 & 13.38 & 1.08 \\
\hline AB-17-29 & 8 & 11.99 & 1.16 & 13.14 & 1.21 \\
\hline AB-17-31 & 3 & 12.15 & 0.50 & 13.91 & 0.14 \\
\hline AB-17-32 & 2 & 11.69 & 0.30 & 13.52 & 0.58 \\
\hline AB-17-33 & 3 & 12.46 & 2.34 & 14.04 & 1.43 \\
\hline AB-17-36 & 3 & 10.68 & 0.53 & 12.90 & 0.64 \\
\hline $\mathrm{AB}-17-37$ & 3 & 12.10 & 1.05 & 13.83 & 0.61 \\
\hline $\mathrm{AB}-17-38$ & 18 & 12.43 & 1.62 & 13.81 & 1.32 \\
\hline $\mathrm{AB}-17-39$ & 5 & 11.38 & 0.81 & 12.89 & 1.07 \\
\hline AB-17-40 & 7 & 10.94 & 1.40 & 12.97 & 1.10 \\
\hline $\mathrm{AB}-17-42$ & 7 & 11.72 & 0.81 & 13.18 & 0.90 \\
\hline $\mathrm{AB}-17-44$ & 21 & 11.37 & 2.25 & 13.33 & 1.66 \\
\hline $\mathrm{AB}-17-55$ & 5 & 10.71 & 0.56 & 1.97 & 167 \\
\hline
\end{tabular}

Note: Mean track length and c-axis projected mean track lengths and their error

estimates were calculated using the HeFTy 1.9.1. program of [11]. $n$ : number of track lengths measured. 

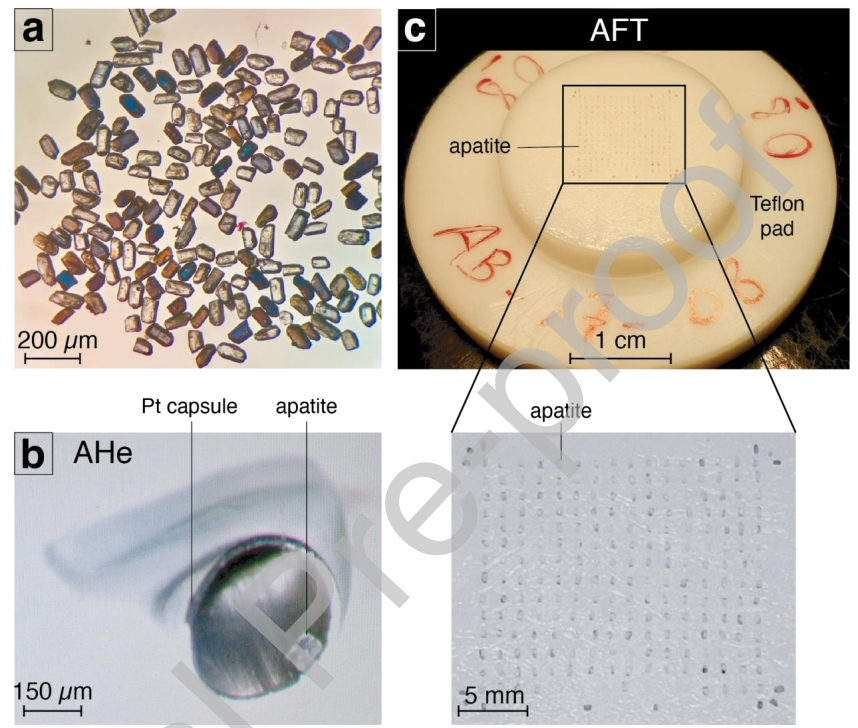

$150 \mu \mathrm{m}$

Figure 1. Sample preparation protocols for AHe and AFT dating. a) Apatites during manual selection under binocular microscope. b) Apatite encapsulation into a platinum cylinder for $\mathrm{AHe}$ dating protocol after initial sorting and selection. c) Apatites arranged on a Teflon pad before casting the epoxy resin (example from the sample AB-17-08). 